\title{
PERAN PENYULUH PERTANIAN DALAM MENDUKUNG KETAHANAN PANGAN PADA SAAT WABAH PANDEMI COVID-19
}

\author{
The Role Of Agricultural Extensions In Supporting Food Security During \\ The Pandemi Covid-19
}

\author{
Sudarmansyah, Ruswendi, Andi Ishak, Emlan Fauzi, Shannora Yuliasari dan \\ Jhon Firison \\ Balai Pengkajian Teknologi Pertanian Bengkulu \\ sudarmansyahvino@ymail.com
}

\begin{abstract}
ABSTRAK
Peran Penyuluh Pertanian sangat ditentukan oleh situasi yang dihadapi di lapangan. Penelitian ini bertujuan untuk mengetahui peran Penyuluh Pertanian dalam mendukung ketahanan pangan pada saat wabah pandemi covid 19. Data dikumpulkan dari hasil penelusuran informasi berita media online sejak bulan Maret - Juli 2020. Informasi yang dikumpulkan berupa konten kegiatan penyuluhan yang terkait dengan ketahanan pangan dari sumber media online yaitu situs berita online dan situs pemerintah tentang peran penyuluh dalam mendukung ketahanan pangan pada saat wabah pandemi covid 19. Informasi yang diperoleh dianalisis secara deskriptif. Hasil analisis menunjukan bahwa peran penyuluh dalam melakukan kegiatan Penyuluhan pada saat wabah pandemi covid 19 yaitu peran penyuluh sebagai pendukung kebijakan program pemerintah, motivator bagi petani dan fasilitator dalam mendukung kegiatan usahatani. Secara khusus, peran penyuluh lebih banyak di arahkan pada upaya dalam rangka mempertahankan ketahanan pangan $(71.15 \%)$ terutama untuk komoditas padi yakni sebesar $54 \%$ dengan cara metode penyuluhan langsung menggunakan protokol covid 19 sebanyak $79 \%$.
\end{abstract}

Kata kunci : peran penyuluh, ketahanan pangan, pandemi covid 19, media online.

\section{PENDAHULUAN}

Pertanian merupakan sektor yang sangat penting dalam perekonomian nasional. Pembangunan ekonomi masih akan tetap berbasis pertanian secara luas. Namun, sejalan dengan tahapan-tahapan perkembangan ekonomi maka kegiatan jasa-jasa dan bisnis berbasis pertanian juga akan semakin meningkat, dengan kata lain kegiatan pertanian akan menjadi salah satu kegiatan unggulan pembangunan ekonomi nasional dalam berbagai aspek yang luas.
Salah satu mata pencaharian utama bagi penduduk Indonesia sekaligus sebagai penyokong perekonomian nasional yakni pada sektor pertanian, artinya sektor pertanian berperan penting serta menjadi penggerak untuk kegiatan perekonomian. Penduduk Indonesia yang bekerja di sektor pertanian pada tahun 2019 sebanyak 38.109.196 dengan jumlah penduduk 237 641326 jiwa, dan sisanya bekerja di bidang lain (BPS, 2020).

Ketahanan Pangan adalah kondisi terpenuhinya Pangan bagi negara sampai 
dengan perseorangan, yang tercermin dari tersedianya Pangan yang cukup, baik jumlah maupun mutunya, aman, beragam, bergizi, merata dan terjangkau serta tidak bertentangan dengan agama, keyakinan, dan budaya masyarakat untuk dapat hidup sehat, aktif, dan produktif secara berkelanjutan (Permentan Nomor 131/Permentan/OT.140/12/2014).

Masalah ketahanan pangan menjadi sangat penting sekaligus rentan bermasalah pada situasi bencana, termasuk bencana wabah penyakit seperti pandemi COVID19. Ketahanan pangan mengindikasikan pada ketersediaan akses terhadap sumber makanan sehingga dapat memenuhi kebutuhan dasar (Rosales \& Mercado, 2020). Kondisi pandemi COVID-19 ini mengakibatkan ketersediaan akses terhadap makanan akan diperparah dengan semakin memburuknya pandemi itu sendiri serta larangan-larangan perpindahan penduduk yang mengikutinya. Hal ini juga sesuai dengan dengan Burgui (2020), yang menyatakan bahwa wabah suatu penyakit yang terjadi di dunia akan meningkatkan jumlah penduduk yang mengalami kelaparan dan malnutrisi.

Penyuluhan merupakan keterlibatan seseorang untuk melakukan komunikasi informasi secara sadar dengan tujuan membantu sasarannya memberikan pendapat sehingga dapat membuat keputusan yang benar. Kegiatan tersebut dilakukan oleh seseorang yang disebut penyuluh pertanian (Van Den Ban dan Hawkins, 1999). Hal ini sesuai dengan pernyataan Kartasapoetra (1994) yang menyatakan penyuluh pertanian merupakan agen bagi perubahan perilaku petani, yaitu mendorong petani mengubah perilakunya menjadi petani dengan kemampuan yang lebih baik dan mampu mengambil keputusan sendiri, yang selanjutnya akan memperoleh kehidupan yang lebih baik. Melalui peran penyuluh, petani diharapkan menyadari akan kebutuhannya, melakukan peningkatan kemampuan diri, dan dapat berperan di masyarakat dengan lebih baik, serta mampu meningkatkan ketahanan pangan bagi keluarga, masyarakat, bangsa dan negara .

Meskipun penyuluh berupaya dengan petani atau kelompok tani untuk menjalankan pembangunan pada sektor pertanian akan tetapi masih diperlukan kebijakan pemerintah yang berpihak pada penyuluh. Kekhawatiran pemerintah serta berbagai pihak mengenai kelangkaan bahan pangan ternyata tidak memudahkan petani sebagai penyedia pangan untuk masyarakat. Petani, sebagai produsen makanan justru menjadi pihak paling terdampak dalam ancaman krisis ketahanan pangan, padahal petani 
merupakan profesi tunggal penyedia pangan yang seharusnya mampu tetap bertahan di tengah pandemi COVID-19.

Upaya pemerintah untuk memutus meluasnya mata rantai penyebaran virus corona dengan melakukan Pembatasan Sosial Berskala Besar Dalam Rangka Percepatan Penanganan Corona Virus Disease (Peraturan Pemerintah nomor Nomor 21 Tahun 2020). Adanya pembatasan sosial berskala besar ini menyebabkan terbatasnya akses bagi penyuluh pertanian dalam melakukan perannya sebagai motivator, fasilitator, serta sebagai pendukung kebijakan program pemerintah. Sementara upaya strategi pemerintah dalam pemenuhan Pangan bagi negara sampai dengan perseorangan tetap menjadi prioritas yang harus dijalankan. Kehadiran media online di harapkan sebagai ruang / wadah bagi pemangku kebijakan, penyuluh pertanian dan petani dalam mengakses informasi yang terkait langsung dengan berbagai kegiatan terkait dengan bidang pertanian dalam rangka mendukung ketahanan pangan di tengah wabah pandemi covid 19.

Media online merupakan media yang berbasis telekomunikasi serta multimedia (Zarrella dan Prihantoro, 2011), yang di dalamnya terdapat portal, website, radio online, tv online, pers online, serta yang
lainnya.Yang paling umum saat ini dan menjadi acuan adalah berupa situs berita online .Situs berita ataupun portal online sesuai dengan namanya merupakan media atau pintu gerbang sebuah informasi yang memungkinkan pengakses mendapat informasi serta aneka fitur serta fasilitas online dan berita yang termuat di dalamnya dengan menggunakan akses internet mereka.

Begitu derasnya informasi teknologi melalui media online baik yang berasal dari sumber situs berita online maupun situs pemerintah terkait dengan berbagai kegiatan di bidang pertanian dalam rangka upaya mendukung ketahanan pangan di tengah wabah pandemi covid 19, sehingga semua orang dapat mencari dan mendapatkan informasi sesuai yang diinginkannya. Peran penyuluh pertanian sangat penting dalam pemberdayaan masyarakat petani. Selain itu peran penyuluh pertanian sebagai fasilitator, motivator dan sebagai pendukung program kebijakan pemerintah serta merupakan titik sentral dalam memberikan penyuluhan kepada petani (Samsudin, 1994).

Pada konteks peran penyuluh mendukung ketahanan pangan, menarik untuk dianalisis bagaimana peran penyuluh pertanian dalam mendukung ketahanan pangan pada saat wabah pandemi covid 19. yaitu peran penyuluh 
sebagai pendukung kebijakan program pemerintah, motivator bagi petani dan fasilitator dalam mendukung kegiatan usahatani. Oleh karena itu, penelitian ini bertujuan untuk mengetahui peran Penyuluh Pertanian dalam mendukung ketahanan pangan pada masa pandemi covid 19.

\section{METODE PENELITIAN}

Penelitian ini menggunakan metode analisis deskriptif. Penelitian deskriptif merupakan penelitian yang berusaha mendeskripsikan suatu gejala, peristiwa dan kejadian yang terjadi pada saat sekarang dimana peneliti berusaha memotret peristiwa dan kejadian yang menjadi pusat perhatian untuk kemudian digambarkan sebagaimana adanya (Sudjana dan Ibrahim, 1989:64; Ali, 1982:120).

Informasi dikumpulkan dari hasil penelusuran konten berita media online dari bulan Maret - Juli 2020. Sumber berita yaitu Situs berita online sebanyak 44 artikel Dan Situs pemerintah sebanyak 8 artikel. Sumber berita dari situs berita online yang dikutip sebanyak 27 Situs, sedangkan dari situs pemerintah sebanyak 7 situs.

Informasi yang dikumpulkan berupa konten kegiatan penyuluhan yang mendukung ketahanan pangan dari sumber media online yaitu situs berita online dan situs pemerintah tentang peran penyuluh dalam mendukung ketahanan pangan pada masa pandemi covid 19. Informasi yang diperoleh dianalisis secara deskriptif.

\section{HASIL DAN PEMBAHASAN}

\section{Kegiatan Penyuluh Pertanian Pada Saat} Wabah Pandemi Covid 19

Pada saat wabah pandemi covid 19 Kegiatan penyuluhan pertanian tidak lepas dari sorotan pemberitaan dari berbagai media online diantaranya yaitu situs berita online dan situs pemerintah. Gambar 1 menunjukkan kegiatan penyuluh pertanian di dalam pemberitaan media online pada saat wabah pandemi covid 19. 


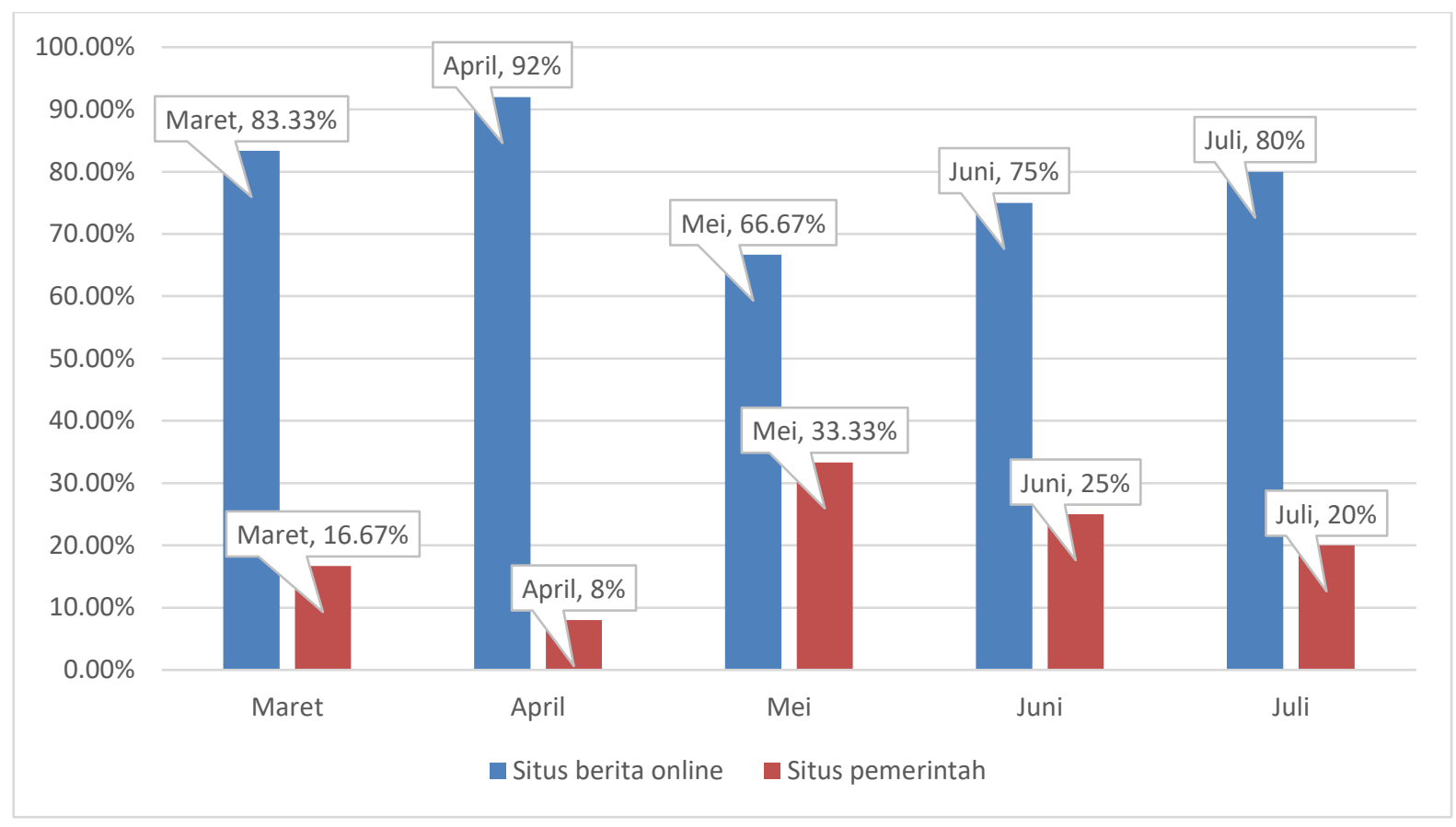

Gambar 1. Sumber pemberitaan pada saat pandemi covid 19 priode maret - juli 2020

Terlihat dari gambar 1. Bahwa setiap pemberitaaan dari media situs berita online lebih tinggi dari pemberitaan yang bersumber dari media situs pemerintah, hal ini sebabkan karena tujuan utama dari media situs berita online lebih mengarah kepada kepentingan komersil / ekonomi, sementara bagi media situs pemerintah dalam pemberitaannya relatif lebih stabil dari bulan ke bulan, hal ini dikarenakan media situs pemerintah dalam pemberitaannya hanya untuk memberikan informasi semata bukan untuk kepentingan ekonomi bagi organisasi/lembaga/instansinya. Jika dilihat dari pola gambar di atas menunjukan bahwa kegiatan pemberitaan dalam rangka pemenuhan informasi dalam upaya penanganan ketahanan pangan pada masa pandemi covid 19 yang bersumber dari media situs pemerintah akan relatip seimbang.

Sementara posisi penyuluh yang dimuat dalam rubrik pemberitaan sebagai peran penyuluh dalam mendukung ketahanan pangan di masa wabah pandemi covid 19 terlihat pada gambar 1 itu akan lebih banyak di soroti oleh media situs berita online, oleh karena itu penyuluh harus pandai memain peran dalam melakukan tugas dan fungsinya selaku penyuluh pertanian sehingga keberadaan media situs berita online dapat dimanfaatkan secara optimal untuk meningkatkan publikasi yang terkait dengan inovasi teknologi pertanian dalam 
rangka mendukung ketahanan pangan. Oleh karena itu, peran penyuluh akan sangat dibutuhkan oleh media situs berita online. Media online adalah media massa yang tersaji secara online di situs web (website) internet. Media Online merupakan produk jurnalistik online (cyber journalism) didefinisikan sebagai pelaporan fakta atau peristiwa yang diproduksi dan didistribusikan melalui internet. (Romli, 2012)

\section{Pemberitaan Media Online Terhadap} Peran Penyuluh Pertanian Pada Saat Wabah Pandemi Covid 19

Peran penyuluh pertanian pada saat wabah pandemi covid 19 di dalam pemberitaan media online yaitu peran penyuluh sebagai fasilitator, motivator dan pendukung. Gambar 2 menunjukkan pemberitaan media online terhadap peran penyuluh pertanian pada saat wabah pandemi covid 19.

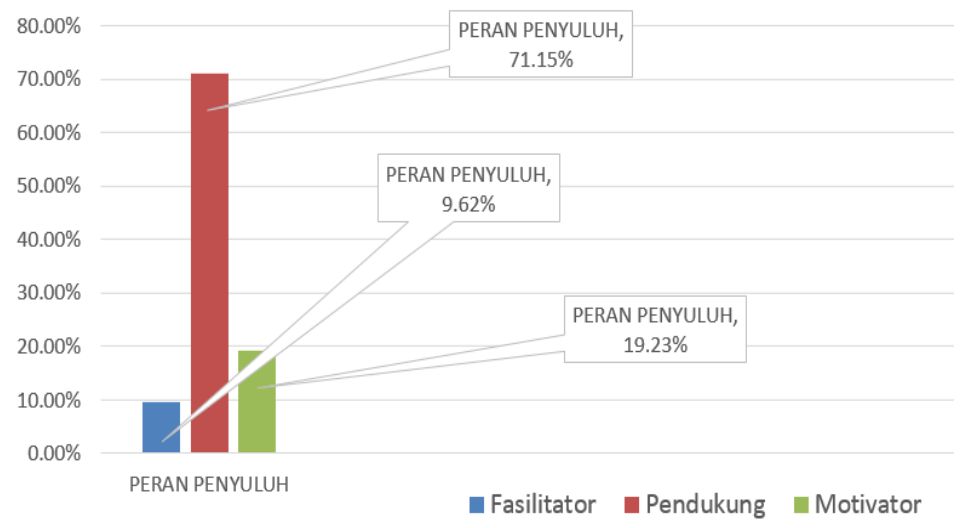

Gambar 2. Peran penyuluh pada masa pandemi covid 19.

Seorang penyuluh mempengaruhi sasaran melalui perannya sebagai motivator, fasilitator, serta pendukung kebijakan program pemerintah (Marbun et al, 2019). Berdasarkan Peraturan Menteri Pertanian Nomor 03/Permentan/SM.200/1/2018. Penyelenggaraan Penyuluhan Pertanian dilaksanakan berdasarkan kebijakan dan strategi. Kebijakan dilakukan secara terintegrasi dengan program pembangunan pertanian untuk mewujudkan kedaulatan pangan dan kesejahteraan petani melalui pendekatan kawasan pertanian. Strategi dilakukan dengan mengembangkan kemampuan, pengetahuan, keterampilan, 
dan sikap Pelaku Utama dan Pelaku Usaha yang profesional.

Peran penyuluh pada saat covid 19 dapat dilihat pada gambar 2 yakni sebesar $75.15 \%$ lebih banyak diarahkan pada mendukung program pemerintah, hal ini sejalan dengan strategi pemerintah pada saat ini yang lebih menekankan kepada upaya dalam memperkuat ketahanan pangan, sperti gerakan percepatan tanam padi di seluruh wilayah Indonesia. Sementara peran penyuluh sebagai motivator yakni sebesar $19.23 \%$ berada pada posisi lebih tinggi dari peran penyuluh sebagai fasilitator, hal ini ini disebabkan karena intensitas pertemuan penyuluh terhadap petani atau pengguna dalam rangka melakukan aktivitas penyuluhannya lebih terbatas hal ini dikarenakan sejalan dengan upaya kebijakan pemerintah dalam rangka memutus mata rantai penyebaran wabah pandemi covid 19 yakni dengan memberlakukan pembatasan sosial berskala besar.

Peran penyuluh sebagai fasilitator pada saat wabah pandemi covid 19 ini dalam rangka melakukan aktivitas kegiatan penyuluhannya kepada petani tentunya akan mengalami penurunan, hal ini akan memiliki dampak pada penyuluh yang memiliki kedudukan dalam perannya sebagai fasilitator terhadap petani dalam melakukan proses penyuluhannya yang selama ini dengan cara pertemuan langsung atau tatapmuka secara langsung dalam rangka mendukung ketahanan pangan akan lebih banyak dilakukan dengan cara pertemuan secara tidak langsung.

\section{Metode Penyuluhan Pada Saat Wabah Pandemi Covid 19}

Pada saat kondisi wabah pandemi covid 19 peran penyuluh dalam melakukan kegiatan penyuluhannya dengan metode penyuluhan langsung dan metode penyuluhan tidak langsung. Berdasarkan Peraturan Menteri Pertanian Nomor : 52/Permentan/OT.140/12/2009. Metode penyuluhan pertanian di tinjau dari teknik komunikasi terdiri dari 2 metode penyuluhan yaitu metode penyuluhan langsung dan metode penyuluhan tidak langsung. Metode Penyuluhan Langsung dilakukan melalui tatap muka dan dialog antara penyuluh pertanian dengan pelaku utama dan pelaku usaha, antara lain: demonstrasi, kursus tani, obrolan sore. Sementara Metode Penyuluhan Tidak Langsung dilakukan melalui perantara (media komunikasi), antara lain: pemasangan poster, penyebaran brosur/leaflet/folder/majalah, siaran radio, televisi, pemutaran slide dan film. Gambar 3 menunjukkan metode penyuluhan yang 
digunakan penyuluh dalam peran mendukung ketahanan pangan pada saat wabah pandemi covid 19. melakukan kegiatan penyuluhannya agar lebih selektif terhadap materi penyuluhan yang akan disampaikan kepada petani untuk menggunakan metode penyuluhan yang tepat guna, tepat sasaran dan tepat waktu, bukan hanya sebatas kegiatan penyuluhan pada masa pandemi covid 19 ini saja namun hal ini dapat dimanfaatkan pada masa mendatang dalam rangka mendukung

program strategis

Gambar 3. Metode penyuluhan pada masa covid 19

Metode penyuluhan pertanian pada masa wabah pandemi covid 19 seperti terlihat pada gambar 3 adalah menunjukan bahwa metode penyuluhan langsung dengan menggunakan acuan tata tertib / protokol covid 19 yakni sebanyak 79\%, sejalan dengan data hasil penelusuran informasi yang kami peroleh dari media online bahwa pelaksanaan penyuluhan dengan menggunakan metode ini yakni terkait dengan hal-hal yang sifatnya lebih ke arah teknis yang seyogyanya pelaksanaan penyuluhannya harus dilakukan dengan cara tatap muka langsung. Sementara metode penyuluhan tidak langsung berdasarkan gambar 3 prosentasenya lebih rendah dari metode penyuluhan langsung yakni sebanyak $21 \%$, hal ini menggambarkan bahwa metode penyuluhan tidak langsung pada situasi wabah pandemi covid 19 sudah tepat penggunaannya dikarenakan muatan penyuluhan yang disampaikan kepada petani lebih mengarah kepada hal-hal yang sifatnya berupa petunjuk teknis, petunjuk pelaksanaan, rekomendasi, serta berupa kebijakan program pemerintah dalam rangka mendukung ketahanan pangan pada masa wabah pandemi covid 19, sehingga metode penyuluhan yang efektif cukup dengan cara virtual saja.

Dari uraian diatas dapat dijadikan acuan bagi penyuluh pertanian dalam pemerintah di bidang pertanian.

\section{Fokus Sasaran Komoditas Yang Dilakukan Pada Saat Wabah Pandemi Covid 19}

Fokus sasaran komoditas dalam rangka Peran penyuluh mendukung ketahanan pangan yang dilakukan di saat wabah pandemi covid 19 berdasarkan hasil penelusuran pemberitaan dari media online terdapat 7 sasaran komoditas yaitu pada komoditas padi, jagung, bawang, cabe, sayuran pekarangan, sapi dan non komoditas. Gambar 4 menunjukkan fokus sasaran komoditas penyuluhan yang dilakukan pada saat wabah pandemi covid 19.

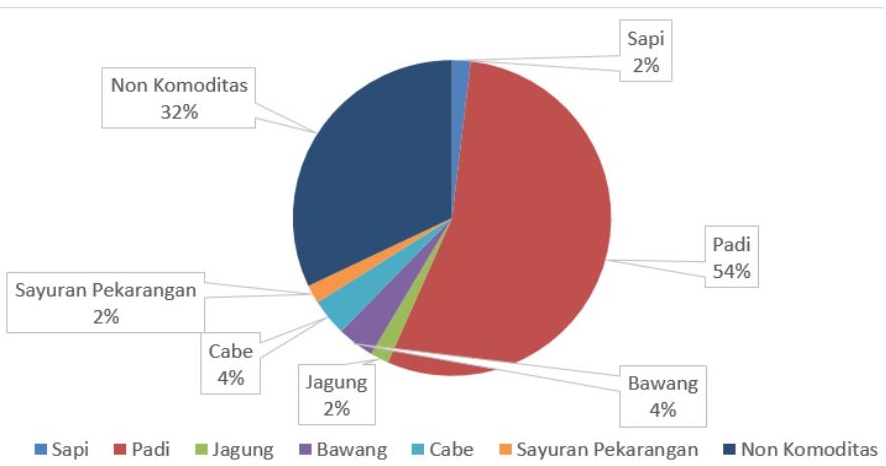

Gambar 4. Sasaran komoditas penyuluhan pada saat wabah pandemi covid 19

Fokus pembangunan pertanian berbasis komoditas tertentu pada masa wabah pandemi covid 19 saat ini, 
dipandang perlu bagi pemerintah untuk melakukan percepatan kebijakan strategis yang lebih berpihak terhadap pemenuhan pangan bagi segenap masyarakat Indonesia. Salah satu langkah yang telah dilakukan pemerintah yakni seperti memberikan prioritas pengembangan pada komoditas pangan utama dalam rangka mendukung ketahanan pangan.

Ilustrasi yang ditunjukan pada gambar 4 menandakan bahwa kegiatan penyuluh pertanian dalam mendukung ketahanan pangan lebih terfokus pada komoditas padi yakni sebesar $54 \%$, artinya arah kebijakan strategis pemerintah saat ini lebih tanggap dalam upaya memperkuat ketahanan pangan. Jika dilihat dari konten pemberitaan yang dimuat pada media situs berita maupun situs pemerintah, isu yang diangkat lebih cenderung kepada topik kegiatan atau materi penyuluhan pada komoditas padi.

Kecukupan pasokan pangan bukan saja vital, tetapi juga merupakan modal utama suatu negara termasuk negeri ini dalam mengatasi dampak pandemih Covid-19. Krisis pangan di tengah pandemi maupun masa pemulihan pascaCovid-19 dapat memicu krisis sosial yang dampak negatifnya sangat besar. Oleh karena itu, berbagai upaya untuk menghindari krisis pangan merupakan agenda kebijakan yang harus menjadi prioritas utama (Pusat Sosial Ekonomi dan Kebijakan Pertanian, 2020).

Pada peringkat kedua dalam gambar 4 diatas fokus sasaran yaitu ditempati oleh non komoditas yakni sebesar $32 \%$. Isu pemberitaannya lebih banyak dibandingkan dengan komoditas bawang dan komoditas cabe yang nilai prosentasenya sama yaitu sebesar $4 \%$ disusul oleh komoditas jagung, sayuran pekarangan dan ternak sapi yang samasama hanya sebesar $2 \%$.

Pada fokus sasaran kedua dapat kita lihat bahwa pemerintah lebih konsen dibandingkan dengan komoditas bawang, cabe, jagung dan sayuran pekarangan, hal ini bukan berarti komoditas ini untuk dikesampingkan pada masa pandemi covid 19 terlihat dari beberapa pemberitaan seperti pemanfaatan pekarangan dalam rangka pemenuhan kebutuhan sayuran skala rumah tangga, tanam jagung dengan pola tumpangsari, serta gerakan tanam cabe dalam media polybag hilangkan stress imbas dari di rumah saja $(\mathrm{CNN}$ Indonesia, 2020).

Sasaran non komoditas dengan nilai sebesar $32 \%$ menunjukan bahwa keberadaannya cukup penting yang mana kegiatan ini adalah diperuntukan dalam rangka mendukung inprastruktur ketahanan pangan pada masa pandemi covid 19 , peran penyuluh pada sasaran ini yakni lebih diarahkan kepada membantu upaya pemerintah dalam mengawal program kebijakan berupa perbaikan sarana prasarana seperti perbaikan irigasi, program bantuan sosial, penyediaan bibit/benih tanaman pangan bagi petani dan gerakan percepatan tanam padi di seluruh Indonesia.

\section{KESIMPULAN DAN SARAN}

Hasil penelitian ini mengggambarkan bahwa peran penyuluh lebih banyak di arahkan pada upaya dalam rangka mempertahankan ketahanan pangan terutama untuk komoditas padi dengan cara metode penyuluhan langsung menggunakan protokol covid 19.

Berdasarkan hasil penelitian ini maka di sarankan bahwa metode penyuluhan langsung menggunakan protokol covid 19 ini bisa dijadikan sebagai suatu pendekatan baru bagi kegiatan penyuluhan pertanian untuk masa yang akan datang, diharapkan bagi pemangku kebijakan agar dapat memfasilitasi kegiatan penyuluhan pertanian berupa regulasi sebagai pedoman bagi penyuluh untuk panduan penyuluhan dengan protokol covid 19 pada kondisi saat wabah pandemi covid 19. 


\section{DAFTAR PUSTAKA}

Antaranews.com, "Meski pandemi COVID-19, Kementan sebut penyuluh tetap dampingi petani." $18 \quad$ April 2020. https://www.antaranews.com/berita /1424909/meski-pandemi-covid19-kementan-sebut-penyuluhtetap-dampingi-petani. Diakses pada 20 April 2020.

Antaranews.com, "Penyuluh pertanian ikut sosialisasikan protokol kesehatan pencegahan COVID-19." 18 April 2020.

https://jambi.antaranews.com/berit a/384052/penyuluh-pertanian-ikutsosialisasikan-protokol-kesehatanpencegahan-covid-19. Diakses pada 20 April 2020.

Antaranews.com, "Penyuluh pertanian tetap dampingi petani di tengah wabah COVID-19.” 16 April 2020. https://jambi.antaranews.com/berit a/383632/penyuluh-pertaniantetap-dampingi-petani-di-tengahwabah-covid-19. Diakses pada 20 April 2020.

Bekasikab.go.id, "Hari Krida Pertanian Momentum Rasa Syukur Petani Di Kabupaten Bekasi.” 23 Juni 2020. http://bekasikab.go.id/berita/2659/h ari-krida-pertanian-momentumrasa-syukur-petani-di-kabupatenbekasi. Diakses pada 29 Juni 2020.

BeritaSatu.com, "Kostra Tani sebagai Ujung Tombak Ketahanan Pangan." 22 April 2020. https://www.beritasatu.com/bernad us-

wijayaka/nasional/623877/kostratani-sebagai-ujung-tombak-

ketahanan-pangan. Diakses pada 12 Mei 2020.

Bisnis.com, "Panen Raya, Petani di Sumsel Terapkan Protokol Pencegahan Corona." 13 April 2020. https://sumatra.bisnis.com/read/202 00413/533/1226199/panen-rayapetani-di-sumsel-terapkanprotokol-pencegahan-corona. Diakses pada 12 Mei 2020.

BPS. 2020. Penduduk Indonesia yang bekerja pada Sektor Pertanian. Badan Pusat Statistik. Jakarta.

Burgui, D. 2020. "Coronavirus: How action against hunger is responding to the pandemic." https://www.actionagainsthunger.o $\mathrm{rg} /$ story/coronavirus-how-actionagainst-hungerrespondingpandemic. Diakses pada 2 Mei 2020

Cnnindonesia.com, "Tanam Sendiri di Rumah: 5 Sayuran yang Cepat Tumbuh dan Panen." 6 Mei 2020. https://www.cnnindonesia.com/gay a-hidup/20200504142925-284499853/tanam-sendiri-di-rumah-5sayuran-yang-cepat-tumbuh-danpanen. Diakses pada 3 Juli 2020

Dinas Ketahanan Pangan, Tanaman Pangan dan Hortikultura. (2020). Petani Lampung percepatan tanam saat pandemi corona. Provinsi Lampung: Penulis. Diakses dari https://dinastph.lampungprov.go.id/ detail-post/petani-lampungpercepatan-tanam-saat-pandemicorona

Dinas Pertanian Grobogan. (2020). Dukung Stok Pangan Aman, Petani Di Wirosari Lakukan Percepatan Tanam Padi. Grobogan: Penulis. Diakses dari https://dispertan.grobogan.go.id/ber ita/dukung_stok_pangan_aman_pet ani_di_wirosari_lakukan_percepata

Dinas Pertanian Kalimantan Barat. (2020). Covid-19 Ganggu Aktivitas Pertanian Dan Bisa Turunkan Pendapatan Petani. Kalimantan Barat: Penulis. Diakses dari http://distan.kalbarprov.go.id/node/ $\underline{340}$

Ekbisk.sindonews.com, "Antisipasi Pasca Pandemi, Penyuluh Dorong 
Percepatan Tanam Melalui Kostratani." 14 Mei 2020. https://ekbis.sindonews.com/read/2 8696/34/antisipasi-pasca-pandemipenyuluh-dorong-percepatantanam-melalui-kostratani1589443558. Diakses pada 7 Juni 2020.

Finance.detik.com, "Peran Penyuluh Pertanian Lawan COVID-19 dengan Jaga Stok Pangan." 12 April 2020. https://finance.detik.com/beritaekonomi-bisnis/d-4974406/peranpenyuluh-pertanian-lawan-covid19-dengan-jaga-stok-pangan. Diakses pada 20 April 2020.

Gesuri.id, "Pemerintah Jangan Lupakan Petani." 6 April 2020. https://www.gesuri.id/internal/musl ahuddin-minta-pemerintah-janganlupakan-petani-b1YKmZs62.

Diakses pada 19 April 2020.

Indopos.co.id, "Panen Bawang, Penyuluh Kawal Petani Dompu Tangkal Covid-19." 19 Juni 2020. https://indopos.co.id/read/2020/06/ 19/238864/panen-bawangpenyuluh-kawal-petani-domputangkal-covid-19/. Diakses pada 7 Juli 2020.

Infopublik.solokkota.go.id, "Wabah Covid-19, Petugas Tetap Berikan Penyuluhan Terhadap Petani." 17 April 2020. https://infopublik.solokkota.go.id/ wabah-covid-19-petugas-tetapberikan-penyuluhan-terhadappetani/. Diakses pada 7 Juni 2020.

Inipasti.com, "Masa Pandemi, Kinerja Sektor Pertanian Cemerlang." 3 Juni 2020. https://inipasti.com/masa-pandemikinerja-sektor-pertaniancemerlang/. Diakses pada 7 Juni 2020.

Kalteng Today.com, "Dewan Sebut Keberhasilan Ketahanan Pangan Ada di Penyuluh Pertanian." 27 Juli 2020. https://kaltengtoday.com/dewansebut-keberhasilan-ketahananpangan-ada-di-penyuluhpertanian/. Diakses pada 30 Juli 2020.

Kalteng Today.com, "Tingkatkan Sarana Prasarana Hingga SDM Untuk Wujudkan Swasembada Pangan." 9 Juni 2020.

https://kaltengtoday.com/tingkatka n-sarana-prasarana-hingga-sdmuntuk-wujudkan-swasembadapangan/. Diakses pada 3 Juli 2020.

Kartasapoetra, A. G. 1994. Teknologi Penyuluhan Pertanian. Bumi Aksara. Jakarta.

Kementerian Perdagangan Republik Indonesia. (2020). Budidaya Cabai di Bawah Kelapa Terobosan Petani Muda Sangihe. Jakarta: Penulis. Diakses dari https://ews.kemendag.go.id/berita/ NewsDetail.aspx?v=8347

Lampung.rilis.id, "Penyuluh dan Petani Lampura Panen Jagung." 18 April 2020.

https://lampung.rilis.id/Penyuluhdan-Petani-Lampura-PanenJagung.html. Diakses pada 7 Juni 2020.

Manado Post.id, "Peran Penyuluh Dan Petani Pada Wabah Covid-19." 20 April 2020. http://manadopost.id/read/2020/03/ 23/PENANGGULANGANVIRUS-COVID-19-ANTARAHAK-DAN-KEWAJIBAN/66910. Diakses pada 14 Juni 2020.

Marbun et al. (2019). "Peran Penyuluh Pertanian Dalam Pengembangan Kelompok Tani Tanaman Hortikultura Di Kecamatan Siborongborong, Kabupaten Tapanuli." Jurnal Ekonomi Pertanian Dan Agribisnis3 (3): 537-46.

Medcom.id, "Petani Cabai Panen di Tengah Pandemi Korona.” 27 April 2020.

https://www.medcom.id/ekonomi/b 
isnis/Dkq7XweN-petani-cabaipanen-di-tengah-pandemi-korona. Diakses pada 12 Mei 2020.

Mediaindonesia.com, "Petani dan Penyuluh Pertanian juga Pejuang Lawan Covid-19." 17 April 2020. https://mediaindonesia.com/read/de tail/304877-petani-dan-penyuluhpertanian-juga-pejuang-lawancovid-19. Diakses pada 14 Juni 2020.

Mediaindonesia.com, "Strategi Pertanian Menghadapi Pandemi Covid-19." $30 \quad$ April 2020. https://mediaindonesia.com/read/de tail/308928-strategi-pertanianmenghadapi-pandemi-covid-19. Diakses pada 29 Juli 2020.

Mediaindonesia.com, "Petani Singkawang Tetap Produktif meski Pandemi Covid-19." 4 Mei 2020. https://mediaindonesia.com/read/de tail/310020-petani-singkawangtetap-produktif-meski-pandemicovid-19. Diakses pada 7 Juni 2020.

Mediaindonesia.com, "Saat Pandemi Covid-19, Penyuluh dan Petani Jaga Stok Pangan.” 17 April 2020. https://mediaindonesia.com/read/de tail/304885-saat-pandemi-covid19-penyuluh-dan-petani-jaga-stokpangan. Diakses pada 20 April 2020.

Megapolitan.antaranews.com, "Penyuluh pertanian jadi pejuang ketahanan pangan di saat COVID-19 mewabah." 18 April 2020. https://megapolitan.antaranews.co m/berita/91972/penyuluhpertanian-jadi-pejuang-ketahananpangan-di-saat-covid-19-mewabah. Diakses pada 20 April 2020.

Mercubuana-yogya.ac.id, "Ketahanan Pangan Keluarga ditengah Pandemi Covid-19.” 16 Mei 2020. http://mercubuanayogya.ac.id/berita-6705-ketahananpangan-keluarga-ditengah- pandemi-covid19. Diakses pada 7 Juni 2020.

Metrokalimantan.com, "Dikawal Penyuluh, Poktan Batu Ampar Siap Panen di Tengah Covid-19." 17 April 2020. https://www.metrokalimantan.com/ 2020/04/dikawal-penyuluh-poktanbatu-ampar-siap.html. Diakses pada 12 Mei 2020.

Metrokalimantan.com, "Jadi Garda Terdepan, Petani Siapkan Pangan Hadapi Pandemi Covid-19." 17 April 2020. https://www.metrokalimantan.com/ 2020/04/jadi-garda-terdepanpetani-siapkan.html. Diakses pada 20 April 2020.

MMC Kobar.com, "Penyuluh Pertanian BPP Arsel Tetap Produktif di Tengah Pandemi Covid-19." 18 Mei 2020. http://mmc.kotawaringinbaratkab.g o.id/berita/penyuluh-pertanian-bpparsel-tetap-produktif-di-tengahpandemi-covid-19. Diakses pada 7 Juni 2020.

Mohamad Ali. 1982. Penelitian Kependidikan Prosedur dan Strategi. Angkasa Bandung. Bandung.

Okezone.com, "Wabah COVID-19 Tak Halangi Penyuluh dan Petani Bekerja." 3 April 2020. https://news.okezone.com/read/202 0/04/03/1/2193853/wabah-covid19-tak-halangi-penyuluh-danpetani-bekerja. Diakses pada 19 April 2020.

Peraturan Menteri Pertanian Nomor 03/Permentan/SM.200/1/2018.

Pedoman Penyelenggaraan Penyuluhan Pertanian.

Kementerian Pertanian. Jakarta.

Peraturan Menteri Pertanian Nomor 131/Permentan/OT.140/12/2014. Mekanisme Dan Hubungan Kerja Antar Lembaga Yang Membidangi Pertanian Dalam Mendukung Peningkatan Produksi Pangan 
Strategis Nasional. Kementerian Pertanian. Jakarta.

Peraturan Menteri Pertanian Nomor 52/Permentan/ OT.140/12/2009.

Metode Penyuluhan Pertanian. Kementerian Pertanian. Jakarta.

Peraturan Pemerintah Republik Indonesia Nomor 21 Tahun 2020.

Pembatasan Sosial Berskala Besar

Dalam Rangka Percepatan

Penanganan Corona Virus Disease 2019 (Covid-19). Sekretariat Negara RI. Jakarta.

Pilarpertanian.com, "Di Tengah Ancaman Covid-19, Kalbar Desain Solusi Atasi Ketersediaan Stok Pangan." 2 Mei 2020.

https://pilarpertanian.com/ditengah-ancaman-covid-19-kalbardesain-solusi-atasi-ketersediaanstok-pangan/. Diakses pada 7 Juni 2020.

Pilarpertanian.com, "Petani Kangkung Organik Papua Tetap Produktif Meski Pandemi Covid-19." 3 Mei 2020.

https://pilarpertanian.com/petani-

kangkung-organik-papua-tetapproduktif-meski-pandemi-covid19/. Diakses pada 7 Juni 2020.

Pos-Kupang.com, "Lawan Covid-19 Penyuluh dan Humas Kementan Aktif Lakukan Penderasan Pemberitaan Kebijakan Kementan.” 22 April 2020. https://kupang.tribunnews.com/202 0/04/22/lawan-covid-19-penyuluhdan-humas-kementan-aktiflakukan-penderasan-pemberitaankebijakan-kementan. Diakses pada 3 Juli 2020.

Pusat Sosial Ekonomi dan Kebijakan Pertanian. (2020). Urgensi Peningkatan Produksi untuk Mengamankan Pasokan Pangan Nasional pada Masa Pandemi Covid-19. Jakarta: Penulis. Diakses dari

http://pse.litbang.pertanian.go.id/in d/index.php/covid-19/opini/324- urgensi-peningkatan-produksiuntuk-mengamankan-pasokanpangan-nasional-pada-masapandemi-covid-19

Republika.co.id, "Kostratani Perkuat Peran BPP Bangun Pertanian dari Kecamatan." 24 Juni 2020. https://republika.co.id/berita/qcezx q349/kostratani-perkuat-peran-bppbangun-pertanian-dari-kecamatan. Diakses pada 29 Juni 2020.

Republika.co.id, "Musim Gadu, Petani Merauke Buat Penangkaran Benih Padi." 22 Juli 2020. https://republika.co.id/berita/qdv64 z349/musim-gadu-petani-meraukebuat-penangkaran-benih-padi.

Diakses pada 30 Juli 2020.

Republika.co.id, "Penyuluh Diminta Aktif Identifikasi Lahan Tidur di Matim." 27 Jul 2020. https://republika.co.id/berita/qe4ec 5349/penyuluh-diminta-aktifidentifikasi-lahan-tidur-di-matim. Diakses pada 6 Agustus 2020.

Rmolbengkulu.com, "Jangan Jual Gabah Padi, Wabah Virus Corona Belum Tahu Kapan Akan Berlalu." 30 Maret 2020. https://www.rmolbengkulu.com/rea d/2020/03/30/23332/Jangan-Jual-

Gabah-Padi,-Wabah-Virus-CoronaBelum-Tahu-Kapan-Akan-Berlalu. Diakses pada 20 April 2020.

Romli, A. S. M. (2012). Jurnalistik online. Nuansa. Bandung.

Rosales, G., and Mercado, W. 2020. Effect of changes in food price on the quinoa consumption and rural food security in Peru. Scientia Agropecuaria 11(1): 83-93

Samsudin S, U.1994. Manajemen Penyuluhan Pertanian. Bina Cipta. Bandung.

SuaraKarya.id, "Antisipasi Pasca Pandemi, Penyuluh Dorong Percepatan Tanam Melalui Kostratani.” 14 Mei 2020. https://m.suarakarya.id/detail/1112 14/Antisipasi-Pasca-Pandemi- 
Penyuluh-Dorong-Percepatan-

Tanam-Melalui-Kostratani.

Diakses pada 7 Juni 2020.

Sudjana, Nana dan Ibrahim. 1989. Penelitian Kualitatif dan Kuantitatif. Sinar Baru. Bandung. Swadayaonline.com, "Kolaborasi Penyuluh dan Petani Menjaga Stok Pangan di Masa Pandemi Covid19.” $27 \quad$ Juli 2020. https://www.swadayaonline.com/ar tikel/7051/Kolaborasi-Penyuluhdan-Petani-Menjaga-Stok-Pangandi-Masa-Pandemi-Covid-19/. Diakses pada 29 Juli 2020.

Tabloidsinartani.com, "Begini Intensifikasi Penyuluhan Lewat AOR di Tengah Wabah Covid-19 agar Petani Tetap Produksi Pangan." 18 Maret 2020. https://tabloidsinartani.com/detail/i ndeks/agri-penyuluhan/11690Begini-Intensifikasi-PenyuluhanLewat-AOR-di-Tengah-WabahCovid-19-agar-Petani-TetapProduk. Diakses pada 19 April 2020.

Tabloidsinartani.com, "Sahabat Petani, Penyuluh Pasaman Barat Tetap ke Lapangan." 14 April 2020. https://tabloidsinartani.com/detail/i ndeks/agri-penyuluhan/12168-

Sahabat-Petani-Penyuluh-

Pasaman-Barat-Tetap-ke-

Lapangan. Diakses pada 20 April 2020.

Van Den Ban dan Hawkins. 1999. Penyuluhan Pertanian. Kanisius. Yogyakarta.

Warta Ekonomi.co.id, "Menyelamatkan Sektor Pertanian di Tengah Pandemi Covid-19." 7 Juni 2020. https://www.wartaekonomi.co.id/re ad288882/menyelamatkan-sektorpertanian-di-tengah-pandemicovid-19. Diakses pada 3 Juli 2020.

Warta Ekonomi.co.id, "Meski di Tengah Wabah Corona, Petani di Desa Ini Panen Padi Hingga 12 Ton!." 5 April 2020. https://www.wartaekonomi.co.id/re ad279760/meski-di-tengah-wabahcorona-petani-di-desa-ini-panenpadi-hingga-12-ton. Diakses pada 19 April 2020.

Warta Ekonomi.co.id, "Sokong Pertanian di Tengah Covid-19, BPPSDMP Kementan Gelar FGD Soal Closed Loop." 7 Mei 2020. https://www.wartaekonomi.co.id/re ad284550/sokong-pertanian-ditengah-covid-19-bppsdmpkementan-gelar-fgd-soal-closedloop. Diakses pada 12 Mei 2020.

Wartaegop.com, "Kostratani, Momentum Bangkitnya Penyuluhan Pertanian." $9 \quad$ Maret 2020. http://wartaegov.com/berita275687 /kostratani-momentum-bangkitnyapenyuluhan-pertanian.html. Diakses pada 19 April 2020.

Zarrella Dan Agung Prihantoro. 2011. The Social Media Marketing Book. PT Serambi Ilmu Semesta. Jakarta. 